\title{
An Implication of Buddhist Ethical Teaching on Sustainable Development
}

\section{Buddyjskie nauczenie etyczne a zrównoważony rozwój}

\author{
Gyan Prakash \\ Department of Humanities and Social Sciences, \\ IIT(ISM) Dhanbad, Dhanbad \\ E-mail: gyan@iitism.ac.in,ORCID:0000-0002-1028-2764
}

\begin{abstract}
Ethical teaching of religion has a significant impact on human action. Scripture has always been considered a guideline for human life. However, there is an argument that Buddhist philosophy is dysteleological. Therefore, it is difficult to argue for the virtuous action for protection or restore nature within the early Buddhist framework. This paper is an attempt to argue that Buddha has the main concern for Human suffering and he prescribed the solution or path to get rid of the suffering but there is a significant implication of Buddhist ethical teaching. Therefore, Buddhist ethical teaching can be a significant step towards sustainable development.
\end{abstract}

Key words: early Buddhism, sustainable development, human action

\section{Streszczenie}

Etyczne nauczanie w ramach religii ma znaczący wpływ na ludzkie działanie. Pismo Święte zawsze było uważane za wskazówkę dotyczącą życia ludzkiego. Istnieje jednak argument, że filozofia buddyjska jest dysteleologiczna. Dlatego trudno jest argumentować za cnotliwym działaniem na rzecz ochrony lub przywrócenia natury we wczesnych ramach buddyjskich. Ten artykuł jest próbą argumentowania, że Budda koncentruje się głównie na ludzkim cierpieniu i z góry przewidział rozwiązanie lub ścieżkę pozbycia się tego cierpienia, dlatego buddyjskie nauczanie etyczne może być znaczącym krokiem w kierunku zrównoważonego rozwoju.

Słowa kluczowe: wczesny buddyzm, zrównoważony rozwój, ludzkie działanie

\section{Introduction}

The debate on sustainable development has taken the center stage in all disciplines. A researcher has also an obligation to inform others about the problem of nature. An article, entitled World Scientists' Warning of a Climate Emergency published in BioScience, has claimed about the climate emergency. Authors write, Scientists have a moral obligation to clearly warn humanity of any catastrophic threat and to 'tell it like it is'. On the basis of this obligation and the graphical indicators presented below, we declare, with more than 11,000 scientist signatories from around the world, clearly and unequivocally that planet Earth is facing a climate emergency (Ripple and et al 2020, p. 8). In this paper, the author has suggested that we have to protect and restore nature.
In this paper, I have argued that one can protect nature while following the Buddhist ethical teaching. Buddha has given importance to balance act so that one could not manipulate the natural resources.

The action recommended by religion leaves a significant impact on human action. Because religious teaching has been accepted as a divine guide of life. Therefore, to understand the ethical teaching religion, elucidation and analysis of the teaching are essential. In this paper, I have argued that the need of the hour as suggested by the scientists is also possible by following the Buddha ethical teaching. In this paper, I have taken early Buddhist philosophy because there is an argument that in Indian philosophy, Buddhist philosophy suggests the path only for salvation. Therefore, it will be difficult to talk about nature or sustainable development from the Buddhist 
point of view (Schmithausen, 1997, p. 11, Harris, 1994, p.53, Harris, 1995). For instance, Buddha teaching of four noble truths is all about human suffering, its cause, and its solution. Therefore, Buddhist philosophy is very much dysteleological (Prakash, 2018). In this paper, I have argued that if one subscribes to the Buddhist ethical path than he may not be able to extinguish the natural resources.

\section{Buddhist Ethics}

In this paper, I have taken the early Buddhist text Visuddhimagga. The early Buddhist text Visuddhimagga or Path of Purification is, written by Buddhgosha, an authentic elucidation of the Buddha's word. This text has given detailed practical instruction for the purification of the mind. Purification of the mind is significant for achieving liberation. In the Visuddhimagga, Buddhaghosa analyses such phenomena as the four great elements, the four noble truths, doctrine of dependent co-origination, threefold discipline, five aggregates, elements and spheres in three main headings: the morality of virtue, concentration, and insight. Therefore, this text has both qualities exegetical and scholasticism (Collins 2009, p. 510).

The ninth chapter of Visuddhimagga is dealt with the divine abiding (Brahamvihara-niddesa). This chapter gives detail elucidation of the notion of lovingkindness, compassion, gladness, and equanimity. These four divine abidings have a unique quality. Buddhaghosa writes that all four abidings have recommended for different types of people. For instance, loving-kindness is for a person with much ill will, compassion is for a person who has much cruelty, gladness is for a person who has much aversion and equanimity is for a person who has greed (Nanamoli, 1956, p. 315). So, these bindings are more towards the promotion of the wellbeing of being. According to the text, one who is interested in realizing the ultimate truth or who is meditator he has to follow the ethical teaching. Buddha has taught us the right attitude towards beings through divine abidings. My position is that to live our life happily or balance act, we have to act according to the Buddhist recommended path. Therefore, in the next section of the paper, I will elucidate the ethical teaching Buddha and its implication on sustainable development.

\section{Loving-Kindness}

The text argues that one, who is interested to develop loving-kindness, should review the danger in hate and the advantage in patience because hate has to be abandoned and patience attained in the development of this meditation subject. Here it is significant to understand the consequences of hate. For Visuddhimagga, when a man starts hating a person than eventually his mind is obsessed with hate and result in undesirable consequences in his life. Therefore, one has to refrain from the hate mental state and the easiest way is to develop loving-kindness. Interestingly, the text has also advised not to develop lovingkindness toward the following kind of person: an antipathetic person, a very dearly loved friend, a neutral person and a hostile person. The text has also advised not developed the loving-kindness towards the opposite sex and a dead person (Nanamoli, 1956, p. 291). However, I am not going to elucidate a different kind of person according to text because this is beyond the scope of this paper. Buddha has asked to develop loving-kindness towards all beings. Here it is significant to elucidate the Buddhist notion of being. In the text, Buddgosha gives Patisambhida's reference and elucidates the method of the mid-deliverance of loving-kindness with unspecified pervasion. Buddhaghosa writes May all beings be free from enmity, affliction and anxiety and live happily. May all breathing things... all who are born... all person... all those who have a personality be free from enmity, affliction, and anxiety and live happily (Nanamoli, 1956, p. 292). In this reference, Buddhghosa has explicated that all breathing animals are included. However, developing loving-kindness is not merely giving importance to living creatures. The text argues that developing a self-centered loving-kindness will not help a person in any way. Therefore, one has to develop loving-kindness in this way: I am happy. Just as I want to be happy and dread pain, as I want to live and not to die, so do other beings, too (Nanamoli, 1956, p. 293). It has explicitly argued that one has to give equal importance to others or other living creature's life. Giving importance to another life means that one has deliberate of their future as well. This action will lead a person towards a significant step to sustainable development. Because, once we started to giving importance to living creatures than we also have to think of their future existence and therefore, we will have to work towards the reserve the resource for their use. The exploitation of natural resources only means that we are not much worried about the other living creature who completely dependent on the natural resources for their life and shelter.

Let us elucidate the treatment of the animal in the Buddhist tradition. For Buddhist philosophy, animals are part of the ecosystem and killing animals will lead to a damaged ecosystem. Here it is significant to note that Buddhism has argued that animals are part of the chain of death and birth (Gowans, 2015 , p. 292). It means that animals are also capable of liberation or Buddha-nature is present in all living beings. Buddhist karma (action) theory has argued that intentional action always produces the result of the action and the agent will have to face the reaction of the action. Animal suffering is also due to past bad actions. Therefore, it is saying that one should not kill any being because in the chain of birth and rebirth they have been our family member (Gowans, 2015 , p. 292). It is significant to elucidate the chain 


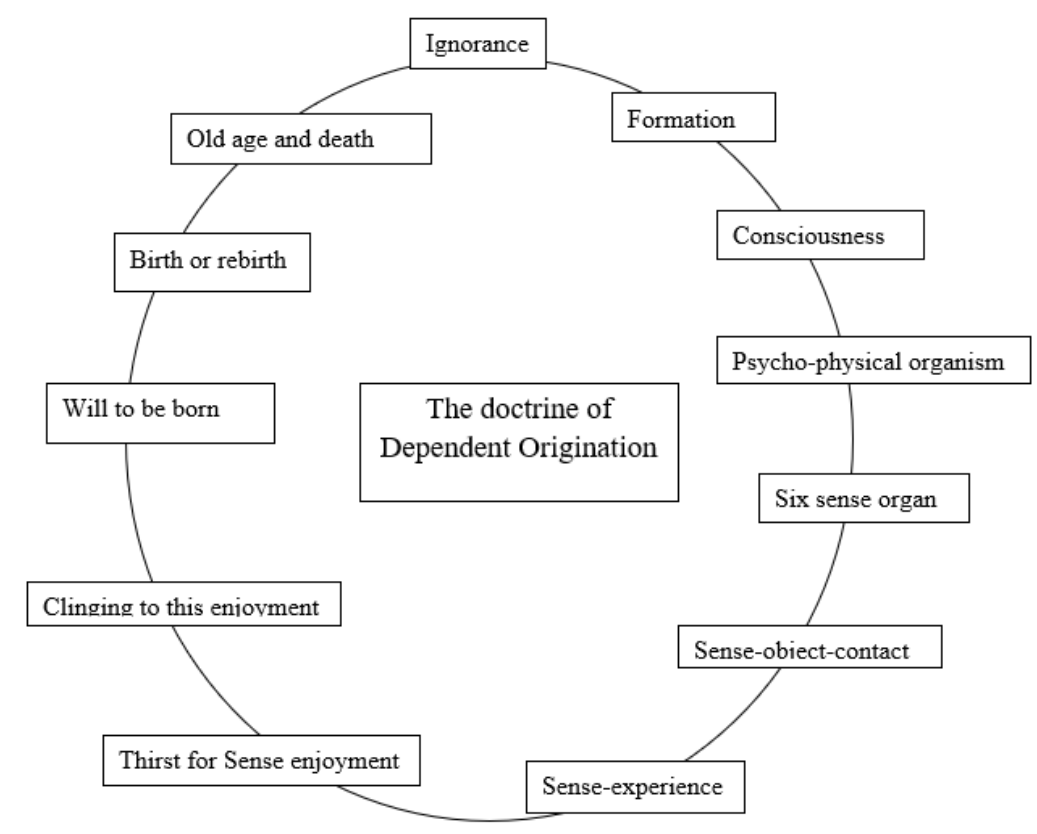

Figure 1. The doctrine of Dependent Origination

of birth and rebirth. To understand the Buddhist notion of a chain of birth and rebirth, let me explicate the theory of action in Buddhist philosophy. Buddha has elucidated the chain of birth and rebirth without the reference of soul and argued that action plays a key role in birth and rebirth.

In the figure 1 it is easy to understand that how Buddha has elucidated the chain of birth and rebirth. It is significant to note that the doctrine of dependent origination means that first is the cause of another. One has to see this chain in terms of cause and effect. In this chain of birth and rebirth karma plays a key role. Because the impression of last action is responsible for the present state and future state. For early Buddhism, our personality is also an effect of our past activities. Therefore, everyone has own way to see the external world. It is significant to elucidate the notion of perception in early Buddhist philosophy. My main intention to elucidate this notion is to show how action and its result affect our life. In early Buddhism, it is mentioned that one complete perception of the object through one sense organ precisely seventeen thought moments must pass. To understand the thought process let us elucidate the seventeen thoughts moment as mentioned in Abhidhammattha Sangaha.

There are seventeen thought moments according to the Buddhist theory which occurs in the different stages of the thought process. (1) The first moment is a passive mental state. This state of mind is considered as subliminal consciousness, where the consciousness manifests in unhindered or like a quiet lake. This state occurs just before the starting of any perception. (2) The second thought-moment is known as adverting. This state of mind is a disturb- ance in the life-continuum or disturbance in the passive mental state. At this stage, the natural flow is checked and is turned towards the object. (3) The third thought-moment is sensation. Sensation or sensuous awareness achieves the function of the seeing in the eye door and having the eye-sensitivity as its physical basis. (4) In early Buddhism after sensation, apprehension thought-moment arises. This is an act of receiving and constituting the raw sense datum. (5) The next state is investigating faculty or the examination of the objects. Here the mind identifies a thing in terms of its experience: once in the past if a person perceived fire, and that idea remains with him, to identify the fire in the present. In early Buddhism, it is mentioned that in this stage mind should have a habit to connect the thing from experience which is placed in the mind through perception.

In this stage of thought process, one can perceive the thing differently. The investigation process occurs on the ground of provided sense datum. (6) After investigation comes the stage of representative cognition termed the determining consciousness. Discrimination is exercised at this stage. This is an act to determine the nature of an object. In this stage, it requires much more than simply looking. Here one determines the object through synthesis. For instance, I am hearing a sound or name of any object then we try to relate the name with the object. This process always occurs before grasping the name or meaning of anything and this same process occurs in the case of composite picture or sensation. Grasping the meaning of any object or name is not a simple process, but one has to come across several processes like imagination, investigation, discrimination, and judgment. This stage of thought processes plays a 
key role to understand the object. (7) Immediately after investigation, a mental state of impulsion arises. This is the psychologically most important stage (Narada 1989, p. 226). At this stage, the action is judged in terms of moral and immoral. (8) This is the final stage of the thought process where a mental state arises with a conclusion about the object.

So far, I have to elucidate the notion of perception in early Buddhist philosophy. The main aim to elucidate to the Buddhist notion of the thought process is to argue that one does not perceive an object as it is. In other words, we cannot perceive an object as it exists or our perception is not the process of mirroring an object. One's emotion or experience plays a key role in perceiving an object. Therefore, Buddhists argue for the subjective world. Here it is significant to note that the impression of one's action shapes the whole personality. In figure 1 it is clear that past action is the main cause of inclination and inclination drives our future action. Therefore, depends on the inclination we act in the future. For Buddhism, in order to achieve liberation one has to exhaust all his inclination and that is not possible in one life. Therefore, one needs many life. Animals are also part of this chain because based on the inclination one gets a future body.

The way out of this problem prescribed by the Buddha was to perform always right action and so no. One has to follow the ethical teaching of Buddha to achieve the liberation and for that purification of the mind is significant. According to Buddhist ethics, Purification is possible only if one starts developing the loving-kindness in his mind. Because this divine abiding can stop evil deed in towards the being. Interestingly, the text has accepted the greed as a near enemy to loving-kindness abiding (Nanamoli, 1956, p. 312). Therefore, this abiding should be well protected from greed. At this point, the text argument proved that if we leave greed aside we will be able to take a significant step towards sustainable development. Because greed is the main cause of all unethical action which is destroying our natural world. Our natural resources can be protected through developing the loving-kindness towards all the breathing creatures. Loving-kindness will also allow us to protect the natural resources for future generations.

\section{Compassion}

The second abiding is Compassion. It is a state where one person cannot see others being in suffering. The main cause of the arising of compassion is to see the helplessness in a person who is overwhelmed by suffering. It does not mean that one should develop compassion for an only dear one. The Buddhist text has argued that Compassion is not for the dear ones, the opposite sex and dead person (Nanamoli, 1956, p. 308). This divine abiding is for another being who is an unlucky or unfortunate person. Buddhagosha writes that one develop compassion towards all the being who is suffering. Compassion can be a significant part of human personality who wanted to take a significant step towards sustainable development. One who practices this divine abiding, may not be able to destroy nature because this may cause the other living creature's suffering. As I have argued above that thinking of other living creature of the future generation will always help one to protect nature or will stop from performing any action which may harm or extinguish the natural resources.

\section{Gladness}

The third abiding is gladness which is always in the sense of gladness at other's success. It is also called appreciative joy (Gowans 2015, p. 190) or altruistic joy (Nanamoli, 1956, p. 309). Appreciative joy or altruistic joy means that one has to feel the joy in others' success or other happiness. Here it is significant to note that, as I have argued earlier in this paper, others mean not only human beings but all breathing creatures. The text argues that if one is suffering in present than one has to develop the gladness by apprehending the future glad aspect in him (Nanamoli, 1956, p. 310). It means that one has to think of the future aspect as well. This attributes of the human personality is lacking in our present society. Nowadays, we are just thinking of our benefit and comfort and using the natural resources for our happiness. Therefore, Buddhist ethical teaching has become more significant in the status quo.

\section{Equanimity}

Equanimity promotes neutrality towards beings. Buddhist philosophy argues that we have to see equality among beings. This abiding promotes the steady consciousness which helps us to perform always virtuous deed in our life. After achieving this state one becomes neutral towards success, failure, pleasure, and pain, etc. The first three abidings are for other beings and the last one, namely equanimity, is for one's state. This divine abiding also important in the sense that this will help an agent to perform the first three abidings. For instance, if a person has achieved this state than he will be always ready to help others being because he is not going to change his mind based on his pleasure, pain and another factor. This abiding promotes a neutral approach to pain and pleasure. He can take a significant step towards sustainable development because exploiting the natural resources occurs only for pleasure or success in one or in another form.

So far, I have been elucidating the Buddhist teaching of divine abidings. These abiding will always help an agent to perform a virtuous action. According to the text, one has to follow the Buddhist teaching in all circumstances. Buddhaghosa writes, Bhikkhus, even if bandits brutally severed limb from limb with a two-handled saw, he who entertained hate in his 
heart on that account would not be one who carried out my teaching (Nanamoli, 1956, p. 294). Following Buddhist teaching with above mentioned Buddha's words can help us to restore or nature or save the natural resources for the future generation. According to the text, Buddha has asked to perform the right action in any situation. Let me put it in other words, one has to think about the welfare of the being and perform the action accordingly. We have to effort for the sustainable development model to restore our nature and Buddhist teaching can guide the individual for the virtuous action.

\section{Conclusion}

In this paper, I have explicated the Buddhist teaching of ethics and argued that the implication of Buddhist ethics is significant for sustainable growth. Following the Buddhist ethics can help to recognize our embeddedness to nature. It is important to remove our alienation from the other living creature. So that one can see everything as part of one's life. Buddhist ethics have always recommended not to harm any living being and one will have to think of the other's wellbeing as well. I have also argued that in early Buddhist philosophy have also argued for the welfare of all the living being. All the living being has the potential to achieve liberation because even animal is part of the chain of birth and rebirth. Therefore, this is our responsibility to think about the welfare of everything and without this one may not be able to achieve the state of happiness.

\section{References}

1. COLLINS S., 2009, Remarks on the Visuddhimagga, and on its treatment of the Memory of former dwelling(s) (punnenivasanussatinana), in: Journal of Indian Philosophy, 37, p. 499-532. DOI: $10.1007 / \mathrm{s} 10781-009-9073-0$.

2. GOWANS C.W., 2015. Buddhist moral philosophy: An Introduction, New York, Routledge.

3. HARRIS, Ian, 1994, Causation and //Telos//: The Problem of Buddhist Environmental Ethics, in: Journal of Buddhist Ethics, 1, p. 45-56.

4. HARRIS Ian, 1995, Getting to Grips with Buddhist Environmentalism: A Provisional Typology, in: in: Journal of Buddhist Ethics, 2, p. 173-190.

5. JAYASURIYA W.F. 1976, The Psychology and Philosophy of Buddhism, B.M.S. Publication, Kuala Lumpur.

6. NARADA M. T., 1989, A Manual of Abhidhamma, Singapore Buddhist Meditation Center, Singapore.

7. NANAMOLI, B. 1956. The Path of Purification, Singapore Buddhist Meditation Centre, Singapore.

8. PRAKASH G., 2018, Buddhist Attitude towards Sustainable Development, in: Problemy Ekorozwojul Problems of Sustainable Development, 13(1), p. 217220.

9. SCHMITHAUSEN L., 1997, The Early Buddhist Tradition and Ecological Ethics, in: Journal of Buddhist Ethics, 4, p. 1-74.

10. RIPPLE W. J., 2020, Christopher Wolf, Thomas. M Newsome, Phoebe Barnard, William R. Moomaw, World Scientists' Warning of a Climate Emergency, in: BioScience, 70(1) p. 8-12, DOI: 10.1093/biosci/biz088. 
